\title{
The practical use of police databases of stolen works of art in the protection of national heritage in selected European Union countries
}

\author{
Jacek Dworzecki
}

Assoc. Prof. Jacek Dworzecki, PhD

Military University of the Land Forces in Wroclaw

Poland

\&

Academy of the Police Force in Bratislava

Slovakia

e-mail: jacekdworzecki@o2.pl

ORCID: 0000-0002-9357-5713

Muzeológia a kultúrne dedičstvo, 2021, 9:2:91-101

DOI: $10.46284 / \mathrm{mkd} .2021 .9 .2 .6$

The practical use of police databases of stolen works of art in the protection of national heritage in selected European Union countries

The effectiveness in the protection of works of art constituting national heritage depends on many factors. These factors include, among other things, binding legal regulations within the scope of the protection of works of art and national heritage sites, good organisation of police forces specialising in this type of activities and cooperation in this field with other state and local government institutions and the wider society. Apart from police officers' commitment and experience, police databases that are dedicated to works of art also play an extremely important role. This article presents selected police databases devoted to works of art that are currently used by police organisations and the role of these databases in protecting national heritage in selected European Union countries. The content of the article was prepared on the basis of the analysis of literature, existing legislation and interviews with police officers and experts. The information obtained during the interviews was subjected to qualitative analysis and presented in a descriptive version.

Keywords: works of art, databases, protection of national heritage, European Union

\section{Introduction}

The global art market is growing dramatically and it continues to undergo significant transformations. ${ }^{1}$ The value of sales on the auction market is increasing, and new price records are being set. The world of art effectively attracts investors who perceive it as a viable alternative to the financial market. For example, the global export of paintings and drawings amounted to $\$ 25.3$ billion in 2019 , achieving an increase of 11 per cent compared to 2018 . According to experts from the United Nations Office on Drugs and Crime (UNODC), the stolen art market is the third-largest area of illicit trade in the world (after drugs and weapons). ${ }^{2}$

Organised criminal groups are also interested in the art market but their activity is not limited to investing money from illegal activity in purchasing paintings, sculptures or graphics. ${ }^{3}$

\footnotetext{
${ }^{1}$ DURNEY, Mark. PROULX, Blythe. Art crime: A brief introduction. In: Crime Law and Social Change, 56, 2011, pp. 115-132.

${ }^{2}$ ULPH, Janet, SMITH, Ian. The illicit trade in art and antiquities: International recovery and criminal and civil liability. Oxford: Hart Publishing, 2012, p. 32.

${ }^{3}$ TORSEN, Molly A. Fine art in dark corners: goals and realities of international cultural property protection. In: Journal of Arts Management, Law and Society, 35, 2005, pp. 89-107.
} 
J. Dworzecki: The practical use of police databases of stolen works of art in the protection of national heritage...

A disturbing phenomenon called artnapping has been growing steadily for several years now. The phenomenon consists in stealing works of art in order to extort a ransom from their legal owners in exchange for their return or using works of art as a bargaining chip in related transactions of a criminal nature, such as drug trafficking. ${ }^{4}$ Works of art stolen in areas of armed conflict are also frequently sold by terrorist organisations and the funds thus obtained are used to finance terrorist activities. ${ }^{5}$

For many decades police from all over the world have been fighting crime on the art market, and their effectiveness has been determined by many factors. ${ }^{6}$ One of the leading tools of police work, which influences the effectiveness of detection activities, is police databases containing information on stolen works of art. The article presents the most advanced databases, which are independent IT instruments created by the police to collect data on works of art, cultural goods and national heritage objects, and the role of these databases in protecting national heritage in selected European Union countries.

The article was prepared based on the available literature on the subject, existing legal acts and the information obtained during interviews with officers involved in fighting crimes related to works of art and national heritage.

Protection of the national heritage in the light of the functioning of databases maintained by selected police units of the European union member states

The management of cultural heritage constantly faces international challenges that cannot be tackled by one country individually. The illicit trade in cultural heritage represents an example of this challenge. The plundering of archaeological sites and international trafficking in cultural goods are serious problems that affect every country. ${ }^{7}$ Counteracting and preventing them requires not only cross-border and sectoral cooperation but also the involvement of public and private institutions as well as society as a whole.

The persistently high prices of works of art on the world markets and the constant increase in their value create a continuing demand for such items, not always from legal sources. The art trafficking market appears to the criminal world as a relatively stable and long-term source of illegal income. ${ }^{8}$ Here are four main reasons why the phenomenon of the theft and smuggling of works of art is increasing:

- the price of paintings and other works of art is rising as a result of their limited supply in the world's antiquarian markets;

- $\quad$ works of art are increasingly considered a good investment and they also serve as a means of money laundering, financing terrorism and organised crime;

- $\quad$ works of art and movable items constituting cultural heritage are used as collateral

\footnotetext{
${ }^{4}$ SCHACK, Haimo. Kunst und Recht. 3 Auflage [Art and law. 3rd Edition]. Heidelberg: Mohr Siebeck, 2017, pp. 171-173.

${ }^{5}$ Interview with Mirosław Lipka from the Civilian Planning and Conduct Capability European External Action Service (National Policy Expert \& Police Expert in the Operations Division CPCC EEAS; in the frame EEAS mission in Iraq, Mr Lipka supervises activities in the field of the protection of works of art and cultural goods located in Iraq). The interview was conducted on May 22, 2020 in Katowice by Jacek Dworzecki.

${ }^{6}$ TIJHUIS, Edgar. Transnational crime and the interface between legal and illegal actors: The case of the illicit art and antiquities trade. Oisterwijk: Wolf Legal Publishers, 2006, pp. 24-25.

${ }^{7}$ CZEGLEDI, Bonnie. Crimes Against Art: International Art and Cultural Heritage Law. Toronto: Carswell Legal Pubns, 2010, p. 26.

${ }^{8}$ TOMPKINS, A. (ed.). Art Crime and its Prevention: A Handbook for Collectors and Art Professionals. London: Lund Humphries, 2016, pp. 11-12.
} 
in the realities of the black economy (e.g. lending by criminal circles);

- as a consequence of the significant liberalisation of trade regulations and increased traffic between individual countries, customs barriers do not effectively protect against the illegal transfer of cultural goods.

Criminals are continually developing not only new methods to steal works of art, but also to obtain cash for them. In the last decade, the most common thefts have occurred in a situation where artworks have been ordered by the owners of private collections, or where the perpetrators of the theft or their agents are planning to ask the owner or the insurance company for a ransom for the return of the stolen work of art. Obviously, there are also attempts to sell stolen works of arton the legal market, but in the era of the global, instant flow of information, it is more and more challenging. However, the vast majority of attempts to sell stolen works of art (according to Interpol's estimates, over 95\%) take place on the black market. Most activities of this type appear in the Internet space, mainly on the so-called Dark Web. For centuries, the illegal acquisition of works of art has also taken place in areas affected by armed conflict, and the perpetrators of such theft are not only professional criminals taking advantage of the opportunity, but also soldiers of the warring parties or occupiers.'

Nowadays, many organisational, legal and technical solutions have been implemented to protect works of art against theft and to identify and find them in the event of the crime. The solutions used are not only preventive, but also educational.

The digitisation of cultural heritage,${ }^{10}$ the creation of IT databases containing information about sold or stolen works of art and other forms of their open presentation in cyberspace ${ }^{11}$ are just some of the modern solutions that have been implemented at this time to protect cultural heritage. Police organisations, apart from regular cooperation in combating criminal offenses, also organise international, coordinated activities aimed at recovering stolen works of art. This type of action incorporates information from IT databases maintained by police units established to protect security, including combating crime related to works of art or carrying out other solutions that result in the protection of cultural heritage.

It should be emphasised that such IT databases dedicated to the protection of cultural heritage are not possessed by the armed forces of any of the European Union countries, which should be regarded as a serious drawback in their functioning. In the course of hostilities in an area of which there are predominantly military units, works of art are stolen and soldiers reveal such situations. Unfortunately, they do not have their own databases and they are not widely trained in order to protect works of art and objects constituting cultural heritage. Therefore, there are circumstances when after the disclosure of a transport containing objects of inestimable value for cultural heritage, said objects may not be retrieved by the military. Furthermore, the cooperation of the armed forces with police organisations in combating crime related to works of art and national heritage on the territory of armed conflicts takes

\footnotetext{
${ }^{9}$ SCHVARC, Michal. „Kulturraub“ or Rescue? The Evacuation of Archives and Other Cultural Heritage by Third Reich Authorities from Slovakia at the End of World War II. In: Muzeológia a kultúrne dedičstvo-Museology and Cultural Heritage, Bratislava, 2013, vol. 1, no. 1, pp. 75-82.

10 ŽABKOVÁ, Soňa. Digitalizácia kultúrneho dedičstva. Projekt: Digitálne múzeum. In: Muzeológia a kultúrne dedičstvo-Museology and Cultural Heritage, Bratislava, 2013, vol. 1, no. 1, pp. 39-48.

${ }^{11}$ ŽUPČÁN, Ladislav. Platforma kultúrneho dedičstva v súčasnej kyberkultúre. In: Muzeológia a kultúrne dedičstvo-Museology and Cultural Heritage, Bratislava, 2019, vol. 7, no. 1, pp. 57-73.
} 
place at a very low level, examples of which are events that occurred during the conflict in Syria. $^{12}$

\section{Database of works of art of the Federal Criminal Office of the Republic of Austria}

After receiving an art theft report, the Austrian police registers the stolen work of art in a specially created IT database on stolen works of art created in 1991 and maintained by the Federal Criminal Police Office. The theft of a work of art or an object of art is registered in the database. The information must include a photograph and a description of the stolen object, including its individual characteristics (e.g. damage) and the security features used. The categories of registrable stolen works of art are consistent with the database maintained by INTERPOL.

The electronic application form includes fields such as:

- Type of object (can be selected: painting, sculpture, drawing, autograph/manuscript, musical instrument, weapon, jewellery, archaeological find, other);

- Material (what material the object is made of. You can select: paper, limewood, sandstone, bronze, white pearl, other);

- Technology (by which the object was made. You can select: woodcut on paper, wood, carved, polychrome and gilded, bronze cast on a wooden base, pencil drawing, watercolour);

- Measurements (height, width, depth - information in centimetres and item weight in grams);

- Title/description (if there is a title or description of the object, e.g. winter landscape, battle scene);

- Artist/writer/producer/designer/workshop (who created the object/work of art);

- Date/period/place of origin/country of origin (when and where the object was made, e.g. Tyrol circa 1480, early seventeenth century, Vienna 1914);

- Inscriptions/signature/marking/inventory number (whether the item has individual identification, e.g. signature, monogram, date, hallmark, number);

- Unique/miscellaneous features (whether the object has any special features that may help identify it, e.g. damage, signs of wear, distinctive restorations, markings on the binding or the underside, inscriptions, dedications);

- Origin (how long the artwork has been in the declarant/owner's possession; from whom it was acquired/inherited; whether the declarant/owner has evidence of the item's origin, e.g. invoices, find reports, export certificates, customs documents, shipping lists; whether the item is listed in publicly available inventories, catalogues, publications; whether there is publicly available photogenic documentation of the item).

The database contains information not only on stolen works of art but also registers objects found as a result of various police activities. When their owner cannot be established, these objects are presented on the publicly accessible website of the Federal Criminal Office of the Republic of Austria. On average, around 200 art thefts are recorded by the Austrian police per year, and the Stolen Art Database contained more than 42,000 registered objects in 2020.

${ }^{12}$ CUNLIFFE, Emma, MUHESEN, Nibal, LOSTAL, Marina. The Destruction of Cultural Property in the Syrian Conflict: Legal Implications and Obligations. In: International Journal of Cultural Property, 2016, no. 23, pp. 1-31. 


\section{ARTIST database maintained by the Art Crime Police Squad of the Organised Crime Department, Directorate for Property Crime of the Federal Police in Belgium}

The ARTIST database (Art Information System) was launched in 1998. Among the data that could be collected in the database one could encounter information on: the owner of the work of art, its name, measurements, place of theft and features allowing for individual identification of the object. Currently, work is underway to further increase the ARTIST database's operational capabilities, including the extension of the possibility to enter photographic and image documentation connecting stolen works of art by means of 3D technology. Moreover, artificial intelligence methods and algorithms are being developed, which should allow more effective penetration of information contained on the Internet in the context of searching for stolen works of art. The functions planned for implementation in the ARTIST database that are also at the stage of testing are:

- geolocalisation of tagged works of art using the PoliceMaps application;

- automatic transmission from the ARTIST database of information on the theft of a work of art to the Protection System for Cultural Heritage (acronym PSYCHE) administered by INTERPOL;

- the integration of the ARTIST database into the database used by Belgian customs;

- automatic email notification to auction houses, antiquarians, licensed dealers in antiques and works of art and online auction shops of registered items that have been stolen, lost or found. ${ }^{13}$

At the beginning of 2020, the ARTIST database contained more than 27,000 works of art stolen in Belgium.

TREIMA information database for cultural and heritage assets used by police forces in France

The largest French IT database on which cultural and national heritage goods are registered is the National Police's TREIMA database. ${ }^{14}$ The database was created in 1995 by officers of the Central Office for Fighting Trafficking in Cultural Goods. The database registers only stolen works of art and objects described as national treasures which are circulating in trade without a reliable, legal source.

Registration in the TREIMA database has two stages: through the electronic stolen object sheet function, which allows for a detailed description of the item/object sought, and through the electronic investigation sheet function in which the investigating units (these are units throughout France) describe the circumstances of the loss of the works of art sought. No estimated value of the stolen work of art is given during the registration process. TREIMA can only be used by the French police forces, i.e. the National Police, the National Gendarmerie and the Paris Police Prefecture. Ministry of Culture employees can also use the database after obtaining permission from the database administrator. The TREIMA database contained more than 100,000 images of stolen items in 2019 as part of more than 32,000 ongoing investigations.

TREIMA is integrated with two databases of the Ministry of Culture, i.e. the MERIMEE

\footnotetext{
${ }^{13}$ Source: Interview with Alain Ruelle from the Belgian Federal Police (Head of CEPOL Belgium). The interview was conducted on June 12, 2018 in Budapest by Jacek Dworzecki.

${ }^{14}$ Source: Interview with Catherine Plano from the France National Police (Senior Adviser at the National Police Academy based in Saint-Cyr-au-Mont-d'Or). The interview was conducted on June 13, 2018 in Budapest by Jacek Dworzecki.
} 
database, which contains data on objects important to the architectural heritage, and the PALISSY database, including data on movable objects important to the cultural heritage of the country. Data on items registered in the TREIMA database are immediately transferred to the abovementioned databases of the Ministry of Culture, which makes attempts at further legal trade in these works of art impossible. ${ }^{15}$

\section{German art database NNSACH}

The German Police maintains a database called NNSACH, which is intended for stolen, fake and dubious works of art. ${ }^{16}$ The NNSACH database can only be accessed (and entered) by trained police officers serving in the BKA and officers from the 16 German states (germ. Land) who investigate works of art. External parties (art dealers, museums, auction houses) that deal with the art market in Germany have indirect access (via the BKA) to the information included in the NNSACH database. This database contains:

- photos of original paintings or other two-dimensional pictorial works;

- information about dubious or fake works of art;

- original registered works of art such as sculptures, furniture, archaeological objects, books.

In 2020, about 21 thousand cases were registered in the NNSACH database with over 60 thousand objects and dating back to World War II.

\section{Discussion}

The interviewed police experts all expressed the view that soon the functioning of databases such as ARTIST, TREIMA and NNSACH will be based on artificial intelligence that will not only allow the identification of stolen or lost objects but that will also make it possible to compare images in virtual space with objects identified on the red lists of $\mathrm{ICOM}^{17}$ and works of art listed for sale on the Internet.

Work based on such assumptions is already in progress under the project acronym PREVISION funded by the European Commission under the programme Horizon 2020. As a result, an interactive IT tool based on AI algorithms is planned to be introduced, which will:

- upload and analyse data from massive heterogeneous data streams;

- constitute an advanced behaviour analytics tool;

- provide a near real-time analysis;

- contain advanced knowledge graphs for associating data;

- contain trend analysis and multivariate behaviour anomaly detection;

- continuously and autonomously learn by using machine learning and anomaly detection techniques;

- $\quad$ be equipped with advanced tailor-made dashboard and visualisation tools;

\footnotetext{
${ }^{15}$ Source: Interview with Catherine Plano from the France National Police (Senior Adviser at the National Police Academy based in Saint-Cyr-au-Mont-d'Or). The interview was conducted on June 13, 2018 in Budapest by Jacek Dworzecki.

${ }^{16}$ SCHWEIZER, Pierre. Datenbanken und Fahndungssysteme der Polizei. München: GRIN Verlag, 2019, p. 11.

${ }^{17}$ International Council of Museums - international non-governmental organisation of museums, created in 1946 with the support of UNESCO in order to represent the interests of museums. ICOM consists of 118 national committees and 30 international specialised committees. The headquarters of the general secretariat is in Paris. ICOMS has approximately 26,000 members in 151 countries. Source: https://icom.museum/en/ (accessed January 27, 2020).
} 
- constitute a future-proof framework;

- comply with the legal, ethical and privacy rules of the EU;

- be able to independently search and analyse data contained in virtual space. ${ }^{18}$

Modern IT tools based on AI are increasingly taking on an offensive character. ${ }^{19}$ The operational abilities of such instruments are continuously increasing, which on the one hand allows the raising of the effectiveness of Police detection operations, and on the other hand can be used for the illegal invigilation of society and the violation of human rights. It is important in the case of police actions taken to protect cultural heritage (as with other policing actions) to exercise appropriate supervision over the use of such IT solutions for the prevention of any misuses.

According to the experts interviewed, a very important issue is also ensuring proper staffing levels in the central level police units, where the databases related to stolen works of art are administrated and where the detective operations in connection with national and international investigations are coordinated. The fact that an adequate number of officers can ensure success in the fight against crimes related to art and cultural heritage is demonstrated by the results obtained by Italian officers from the Carabinieri for the Protection of Cultural Heritage. Taking into consideration that the market for stolen works of art is the third largest area of illicit trafficking in the world (after drugs and weapons), police structures should be expanded adequately to the threat of this type of offence. The standards in this regard introduced by the Italian Republic and the consistent implementation of adopted objectives are set as an example to follow for police organisations of other EU countries by the experts. The abolition or inefficient reorganisation of specialised police units is the main reason for failures in fighting crimes related to art, experts say. According to the experts, over the next 5 years a specialised unit is expected to be set up within Frontex, whose aim is to be the coordination of international operations against organised crime groups which are involved in crimes (mainly theft and smuggling across the European Union and from the EU territory to Russia and China) related to works of art, especially from the territories of armed conflict, as is now happening in Syria, Afghanistan or Ukraine.

Another solution suggested by the experts to improve the security of works of art and cultural goods is the implementation of legal regulations at the EU level, which will oblige member states to introduce rules requiring entities operating in the art market (all entities should also have a licence to deal in the area of works of art) to check in databases that an object of sale is not the result of a criminal offence and that its origin is reliably documented. If the original of an item offered for sale is found to be incorrect, the verifier should be obliged to notify the law enforcement authorities of this situation. In cases of dispute, the sale should

\footnotetext{
${ }^{18}$ Interview with Piotr Tycka, PhD from ITTI Poland. ITTI is an IT company (SME) providing software solutions for companies and institutions in Poland and in other countries. ITTI is a member of the research consortium implementing the PREVISION project. The interview was conducted (on-line) on May 10, 2020 by Jacek Dworzecki. ${ }^{19}$ E.g. the Pegasus platform created by an Israeli company NGO Group. This tool based on artificial intelligence enables the interception of data transmissions without the operator's knowledge and it means that the platform owner is able to eavesdrop on phone calls and read messages sent via instant messaging. In addition, Pegasus has a considerable ability to infect even modern smartphones. Installing the application sometimes requires clicking on a crafted link, but other times it does not require any interaction on the part of the user. This platform is used by US government agencies such as the CIA, ATF and DEA and in Europe by, for example, the Polish Central Anti-Corruption Bureau. Source: Interview with a senior agent, Piotr (full name of the senior agent for the sole information of the author), from the Central Anti-Corruption Bureau (department in Cracow). The interview was conducted on February 23, 2020 by Jacek Dworzecki.
} 
be preceded by an administrative decision of an authorised body charged with the protection of the national heritage and cultural assets of the country concerned.

In the case of technical aspects of the marking of works of art, the experts represent the view that these actions should be made statutory (e.g. as a regulation by the European Parliament) as an obligation for entities operating in the art market. Moreover, the participants of the interviews concluded that the usage of microphotography, ${ }^{20}$ the DNA system ${ }^{21}$ or electronic chips in marking allows the security of works of art to be increased (as well as facilitating identification) with a relatively low cost incurred. Specialised police forensic units, the so-called police forensic laboratories, can assist in this.

In light of the information obtained through interviews with European experts representing police services involved in the fight against art crimes, it is hard to agree with the thesis statement adopted by Ch. Roodt and B. Benson, who in their article under the title "Databases for stolen art: Progress, prospects and limitations" stated that "...Police databases have limited potential for interoperability". ${ }^{22}$ The high interoperability of police databases is due not only to the constant flow of information from the public sector (citizens, institutions, art dealers) about stolen or recovered works of art but also constitutes the effect of the operational and investigative work undertaken by officers in relation to the implementation of statutory tasks of a police character. Moreover, the police databases dedicated to works of art are constantly being modernised and expanded toward the broadening of the capacity of autonomous and detection operations.

\section{Conclusion}

Police organisations around the world undertake a number of actions aimed at preventing and fighting against crimes including in their most serious organised form. ${ }^{23}$ The interest in works of art from international crime groups has already been a reality for several decades. ${ }^{24}$

Furthermore, the art market is subject to criminal mechanisms whereby objects representing the cultural heritage of worldwide significance are sold and terrorist organisations, among others, are involved in these transactions. Art crimes are no longer just the means for enriching criminal groups but they have been increasingly becoming a means of financing terrorist attacks and activities designed to destabilise the security situation in many countries and regions of the world. It is therefore extremely important to implement operations and solutions allowing a more efficient fight by law enforcement against this form of crime.

Without a doubt, the modern IT databases such as ARTIST, TREIMA and NNSACH which police forces have at their disposal today are a leading tool in preventing and fighting against crimes related to works of art and the world's cultural heritage. Within the next decade, this IT tool will be expanded to allow greater freedom for independent actions by the implemented

\footnotetext{
${ }^{20}$ Microphotography is the taking of digital photos of fragments of objects at up to 30-50 times magnification.

${ }^{21}$ The DNA system is the laser marking of works of art with polyester micro-particles of millimetre diameter, with an individual multi-digit identification number (up to 17 digits).

${ }^{22}$ ROODT, Christa, BENSON, Bernadine. Databases for stolen art: Progress, prospects and limitations. In: $S A$ Crime Quarterly, 52, 2015, p. 9.

${ }^{23}$ DWORZECKI, Jacek, NOWICKA, Izabela, URBANEK, Andrzej, KWIATKOWSKI, Adam. Protection of national heritage in the light of the applicable law and the actions provided in this area by police in Poland. In: Muzeológia a kulturne dedičstvo-Museology and Cultural Heritage, Bratislava, 2020, vol. 8, no. 4, pp. 177-198.

${ }^{24}$ BRODIE, Neil, DOOLE, Jennifer, WATSON, Peter. Stealing History: The Illicit Trade in Cultural Material. Cambridge: McDonald Institute for Archaeological Research, 2000, p. 11.
} 
system without human contribution, which will be possible with improved AI algorithms, definitely leading to an increase in the level of modern detection and analytical capabilities.

Systems based on AI will allow the searching through photo resources, including analysis of the pattern of colours and shapes, to help search engines understand what we are dealing with in a painting. In this way, the photographs found on the Internet corresponding (shape, description) to the objects (works of art) searched for on the web will be identified, compared and catalogued. Moreover, police officers will be able to use a function that will allow them to "search by photo" instead of using a textual description. Already today, systems based on the above assumptions are being tested by major IT giants such as Google, which is working on RankBrain algorithms, designed to work with a version of the search engine called Hummingbird.

Undoubtedly, the improvement of IT tools used in the work of police officers dealing with works of art will significantly affect the effectiveness of fighting against this form of crime.

\section{References}

BRODIE, Neil, DOOLE, Jennifer, WATSON, Peter (2000). Stealing History: The Illicit Trade in Cultural Material. Cambridge: McDonald Institute for Archaeological Research, ISBN 97819-02937-10-6.

CHAPPELL, Duncan, HUFNAGEL, Saskia (2014). Contemporary Perspectives on the Detection, Investigation and Prosecution of Art Crime: Australasian, European and North American Perspectives, London: Routledge, ISBN 978-11-38637-69-6.

CUNLIFFE, Emma, MUHESEN, Nibal, LOSTAL, Marina (2016). The Destruction of Cultural Property in the Syrian Conflict: Legal Implications and Obligations. In: International Journal of Cultural Property, 2016, no. 23, pp. 1-31. ISSN 0940-7391 (Print), 1465-7317 (Online).

CZEGLEDI, Bonnie (2010). Crimes Against Art: International Art and Cultural Heritage Law. Toronto: Carswell Legal Pubns, ISBN 978-07-79823-16-1.

DÍTE, Tibor (2013). Limity digitalizácie v ochrane kultúrneho dedičstva spravovaného múzeami. In: Museology and Cultural Heritage, Bratislava, 2013, vol. 1, no. 2, pp. 87-100, ISSN 1339-2204.

DURNEY, Mark. PROULX, Blythe (2011). Art crime: a brief introduction. In: Crime Law and Social Change, 56, 2011, pp. 115-132. ISSN 0925-4994.

DWORZECKI, Jacek, NOWICKA, Izabela, URBANEK, Andrzej, KWIATKOWSKI, Adam. (2020). Protection of national heritage in the light of the applicable law and the actions provided in this area by police in Poland. In: Muzeológia a kulturne dedičstvo-Museology and Cultural Heritage, Bratislava, 2020, vol. 8, no. 4, pp. 177-198, ISSN 1339-2204, e-ISSN 24539759.

IBP USA (2016). Austria Justice System and National Police Handbook Volume 1: Criminal Justice System and Procedures. IBP USA, ISBN 978-14-33003-25-7.

ROODT, Christa, BENSON, Bernadine (2015). Databases for stolen art: Progress, prospects and limitations. In: SA Crime Quarterly, 52, 2015, p. 9. ISSN 1991-3877.

SCHACK, Haimo (2017). Kunst und Recht. 3 Auflage [Art and law. 3rd Edition]. Heidelberg: Mohr Siebeck, ISBN 978-3-16-155037-9.

SCHWEIZER, Pierre (2019). Datenbanken und Fahndungssysteme der Polizei. München: GRIN Verlag, ISBN 978-33-46011-41-1. 
SCHVARC, Michal (2013). „Kulturraub“ or Rescue? The Evacuation of Archives and other Cultural Heritage by Third Reich Authorities from Slovakia at the end of World War II. In: Muzeológia a kultúrne dedičstvo-Museology and Cultural Heritage, Bratislava, 2013, vol. 1, no. 1, pp. 75-82, ISSN 1339-2204.

SURHONE, Lambert M., TIMPLEDON, Miriam T., MARSEKEN, Susan F. (eds, 2010). National Police (France). Betascript Publishing, ISBN 978-613-0-42915-7.

TIJHUIS, Edgar (2006). Transnational crime and the interface between legal and illegal actors: The case of the illicit art and antiquities trade. Oisterwijk: Wolf Legal Publishers, ISBN-13 978-90-5850195-0.

TOMPKINS, A (ed., 2016). Art Crime and its Prevention: A Handbook for Collectors and Art Professionals. London: Lund Humphries, ISBN 978-18-48221-87-1.

TORSEN, Molly A. (2005). Fine art in dark corners: goals and realities of international cultural property protection. In: Journal of Arts Management, Law and Society, 35, 2005, pp. 89-107, ISSN 1063-2921.

ULPH, Janet, SMITH, Ian (2012). The illicit trade in art and antiquities: international recovery and criminal and civil liability. Oxford: Hart Publishing, ISBN 978-15-09905-45-4.

ŽABKOVÁ, Soňa (2013). Digitalizácia kultúrneho dedičstva. Projekt: Digitálne múzeum. In: Muzeológia a kultúrne dedičstvo-Museology and Cultural Heritage, Bratislava, 2013, vol. 1, no. 1, pp. 39-48. ISSN 1339-2204.

ŽUPČÁN, Ladislav (2019). Platforma kultúrneho dedičstva v súčasnej kyberkultúre. In: Muzeológia a kultúrne dedičstvo-Museology and Cultural Heritage, Bratislava, 2019, vol. 7, no. 1, pp. 57-73. ISSN 1339-2204, eISSN 2453-9759.

\section{Law regulations}

The Hague Convention of 14 May 1954 for the Protection of Cultural Property in the Event of Armed Conflict with Regulations for the Execution of the Convention 1954.

COUNCIL DIRECTIVE 93/7/EEC of 15 March 1993 on the return of cultural objects unlawfully removed from the territory of a Member State. Official Journal of the European Communities No L 74/74 published 27.3.93

DIRECTIVE 2014/60/EU OF THE EUROPEAN PARLIAMENT AND OF THE COUNCIL of 15 May 2014 on the return of cultural objects unlawfully removed from the territory of a Member State and amending Regulation (EU) No 1024/2012 (Recast). Official Journal of the European Union L 159/1 published 28.5.2014

REGULATION (EU) 2019/880 OF THE EUROPEAN PARLIAMENT AND OF THE COUNCIL of 17 April 2019 on the introduction and the import of cultural goods. Official Journal of the European Union L 151/1 published 7.6.2019

Recommendations of the expert group on protection against trafficking in cultural property, Commission on Crime Prevention and Criminal Justice, Nineteenth session, Vienna, 17-21 May 2010.

Report from the Commission to the Council, the European Parliament and the European Economic and Social Committee: Third Report on the application of Council Directive $93 / 7 /$ EEC on the return of cultural objects unlawfully removed from the territory of a Member State, Brussels, 30 July 2009. 
UNESCO Convention on the Means of Prohibiting and Preventing the Illicit Import, Export and Transfer of Ownership of Cultural Property, 14 November 1970, 823 UNTS 231; 10 ILM 289.

UN General Assembly Recommendation on the Return or Restitution of Cultural Property to the Countries of Origin A/Res/48/15 of 2 November 1993.

UNIDROIT Convention on Stolen or Illegally Exported Cultural Property, 24 June 1995, 34 ILM 1330; entry into force 1 July 1998.

\section{Other sources}

Code of Ethics of the International Council of Museums (ICOM) 1986 as amended.

Interview with Alain Ruelle from the Belgian Federal Police. The interview was conducted on June 12, 2018 in Budapest by Jacek Dworzecki.

Interview with Catherine Plano from the French National Police. The interview was conducted on June, 132018 in Budapest by Jacek Dworzecki.

Interview with Piotr Tycka, PhD from ITTI Poland. The interview was conducted (on-line) on May 10, 2020 by Jacek Dworzecki.

Interview with Mirosław Lipka from the Civilian Planning and Conduct Capability European External Action Service. The interview was conducted on May 22, 2020 in Katowice by Jacek Dworzecki.

Interview with a senior agent, Piotr (full name of the senior agent for the sole information of the author), from the Central Anti-Corruption Bureau (department in Cracow). The interview was conducted on February 23, 2020 by Jacek Dworzecki. 